\title{
The case of the missing wrist: a probable case of idiopathic osteolysis
}

\author{
Carlo Jan Pati Garingarao, Mark Anthony Santiago Sandoval
}

Department of Medicine, Section of Endocrinology, Diabetes and Metabolism, University of the Philippines, Philippine General Hospital, Manila, Philippines

\section{Correspondence to}

Dr Carlo Jan Pati-an Garingarao, jinggoy83@yahoo. com

\section{DESCRIPTION}

A 49-year-old woman with poorly-controlled diabetes was admitted with gangrene of the right foot. A routine preoperative evaluation revealed upper limb discrepancy with the right arm shorter by $\sim 2 \mathrm{~cm}$ than the left; the area of the wrist is thickened with a spongy consistency (figure 1), but neither warmth nor tenderness noted.

History provided by her family revealed persistent bone pain over the right wrist at 5 years old, with gradual shortening of the involved extremity over the course of 1 year. No precedent trauma was recalled; no formal consult was sought. She recalled no similar symptoms involving other extremities and was able to use the affected extremity fairly well though with a relatively weak grip.

A radiograph of her right forearm revealed absence of all but one of her carpal bones, with irregular outlines of the bases of the metacarpals and prominent soft tissue around the mentioned area (figure 2). Workup showed high glycated haemoglobin (11.9\%) with dyslipidaemia, probable chronic renal insufficiency (eGFR $23.86 \mathrm{~mL} / \mathrm{min} /$ $1.73 \mathrm{~m}^{2}$ ), mild hypercalcaemia at $2.62 \mathrm{mmoL} / \mathrm{L}$ (normal: 2.12-2.5) attributed to mild dehydration and normal phosphorus levels.

On the basis of the history of bone pain, shortening of her right arm with no precedent trauma or infection and a radiograph showing absence of carpal bones, a probable diagnosis of idiopathic osteolysis was made.

\section{A}

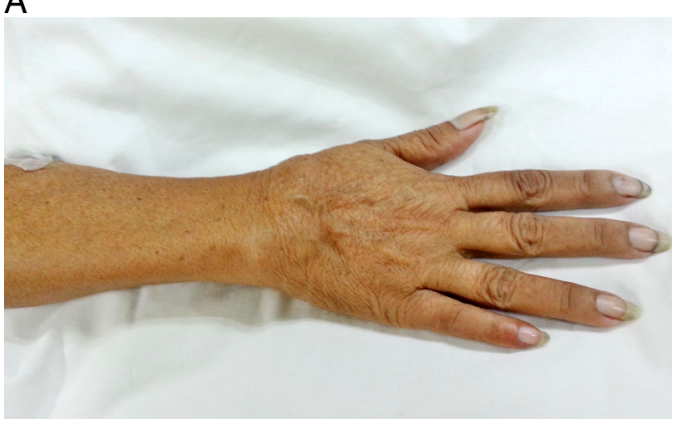

B

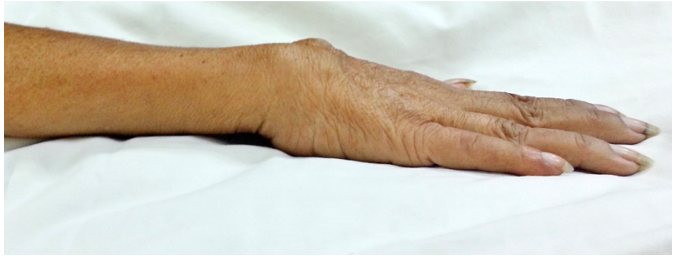

Figure 1 Patient's right forearm, superior $(A)$ and lateral $(B)$ views, showing thickening at the wrist area with no open lesions or signs of inflammation or infection on physical examination.
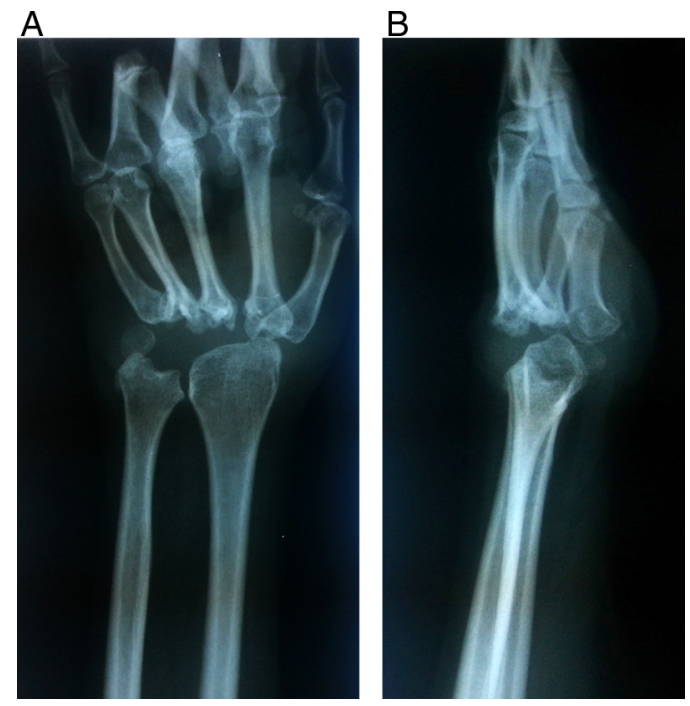

Figure 2 Radiograph of the right forearm, anteroposterior (A) and lateral view (B), showing absence of all but one carpal bones.

She underwent below-the-knee amputation of the gangrenous foot without complications and was discharged on vildagliptin and simvastatin. No further examinations of her right wrist were requested due to the lack of progression of symptoms since childhood.

\section{Learning points}

- Idiopathic osteolysis, Gorham's disease or vanishing bone disease is a rare condition with an uncertain aetiology; theories include hyperactive osteoclastic bone resorption and disorganised lymphangiogenesis. ${ }^{1-3}$

- Causes of secondary osteolysis such as trauma-associated atrophy, primary or metastatic malignancy, hyperparathyroidism, infections (eg, osteomyelitis) or inflammatory arthritis should be ruled out. ${ }^{1}$

- Possible treatment options for progressive disease are radiation therapy, surgical resection, bisphosphonates, $\alpha-2 \beta$ interferon and anti-PGDF monoclonal antibodies. ${ }^{2} 3$

Contributors MASS is the primary admitting physician of the patient during her admission, with CJPG as the endocrinology fellow of the month. Both authors have contributed significantly to the writing of the manuscript.

Competing interests None.

Patient consent Obtained.

Provenance and peer review Not commissioned, externally peer reviewed. 


\section{REFERENCES}

1 Moller G, Priemel M, Amling M, et al. The Gorham-Stout syndrome (Gorham's massive osteolysis). J Bone Joint Surg 1998;81-B:501-6.
2 Radhakrishnan K, Rockson SG. Gorham's disease, an osseous disease of lymphangiogenesis? Ann N Y Acad Sci 2008;1131:203-5.

3 Patel DV. Gorham's disease or massive osteolysis. Clin Med Res 2005;3:65-74.

Copyright 2013 BMJ Publishing Group. All rights reserved. For permission to reuse any of this content visit http://group.bmj.com/group/rights-licensing/permissions.

BMJ Case Report Fellows may re-use this article for personal use and teaching without any further permission.

Become a Fellow of BMJ Case Reports today and you can:

- Submit as many cases as you like

- Enjoy fast sympathetic peer review and rapid publication of accepted articles

- Access all the published articles

- Re-use any of the published material for personal use and teaching without further permission

For information on Institutional Fellowships contact consortiasales@bmjgroup.com

Visit casereports.bmj.com for more articles like this and to become a Fellow 